\title{
ANALISIS PENGGUNAAN BAHASA PROKEM PADA REMAJA DI DESA KUTANEGARA KABUPATEN KARAWANG
}

\author{
Aisah $^{1}$ \\ Universitas Singaperbangsa Karawang ${ }^{1}$ \\ aisah040700@gmail.com \\ Sinta Rosalina ${ }^{2}$ \\ Universitas Singaperbangsa Karawang ${ }^{2}$ \\ sinta@fkip.unsika.ac.id
}

\begin{abstract}
ABSTRAK
Bahasa prokem mencerminkan budaya yang berkembang di masyarakat. Bahasa prokem ini tidak hanya muncul baru-baru ini, tetapi sudah ada sejak lama. Bahasa prokem sudah tidak asing lagi dikalangan masyarakat khususnya para remaja. Penggunaan bahasa prokem pada remaja di Desa Kutanegara Kabupaten Karawang sudah sangat biasa. Semakin majunya zaman semakin banyak bahasa prokem yang baru. Penelitian ini bertujuan untuk mendeskripsikan penggunaan bahasa prokem pada remaja di Desa Kutanegara Kabupaten Karawang. Penelititan ini menggunakan metode deskriptif kualitatif. Objek penelitian ini yaitu remaja yang menggunakan bahasa prokem. Teknik pengumpulan data yaitu dengan cara observasi dan wawancara. Teknik analisis data dengan langkah-langkah reduksi data, menyajikan data, dan meinyimpulkan. Hasil penelitian menunjukkan bahwa 1) Penggunaan bahasa prokem yang biasa dipakai oleh remaja di Desa Kutanegara Kabupaten Karawang, 2) Faktor-faktor penggunaan bahasa prokem, 3) Dampak positif dan negatif penggunaan bahasa prokem.

Kata kunci: bahasa prokem, penggunaan, remaja
\end{abstract}

\section{A. PENDAHULUAN}

Bahasa adalah alat terpenting dalam kehidupan manusia. Tanpa penggunaan bahasa lisan dan tulisan, manusia tidak akan bisa berkomunikasi. Bahasa adalah alat yang digunakan orang untuk berinteraksi dan berkomunikasi satu sama lain. Fungsi umum bahasa yaitu sebagai alat komunikasi dan sosial. Bahasa telah diintegrasikan ke dalam kehidupan manusia, sehingga manusia sebagai makhluk sosial membutuhkan bahasa untuk berkomunikasi. Berdasarkan definisi tersebut, dapat disimpulkan bahwa satu atau lebih ciri suatu bahasa adalah dinamis atau tidak statis. Karena bahasa bersifat dinamis, maka tidak mengherankan jika bahasa terus berubah seiring dengan aktivitas manusia.

Secara umum, perubahan bahasa mencakup dua hal, yaitu perubahan tata bahasa yang disebabkan oleh perubahan internal atau perubahan eksternal, dan perubahan yang disebabkan oleh kontak dengan bahasa lain atau perubahan eksternal. Salah satu efek dari perubahan bahasa internal adalah inovasi dalam masyarakat yang akrab, menghasilkan jargon atau bahasa slang. Jargon digunakan oleh sekelompok orang 
dalam pekerjaan formal, sedangkan bahasa slang digunakan oleh sekelompok orang informal.

Bahasa prokem umumnya digunakan sebagai sarana komunikasi antar remaja untuk kurun waktu tertentu. Hal ini karena remaja memiliki bahasa mereka untuk mengekspresikan diri. Remaja memerlukan fasilitas komunikasi untuk menawarkan halhal yang dianggap tertutup oleh kelompok usia lain atau untuk bagian lain untuk tidak mengetahui apa yang mereka bicarakan. Remaja memiliki fitur yang mencakup petualangan, pengelompokan, dan kejahatan. Fungsi ini juga tercermin dalam bahasa. Keinginan untuk membuat kelompok eksklusif menciptakan bahasa rahasia. Bahasa prokem merupakan gaya linguistik yang mengembangan atau memodifikasi dari berbagai bahasa, termasuk bahasa Indonesia sehingga bahasa tersebut tidak memiliki struktur tertentu dalam gaya bahasa. Sebagian besar kata-kata prokem pada remaja adalah terjemahan dan singkatan. Namun, kadang-kadang kata aneh juga dibuat yang sulit diketahui di awal. Bahasa prokem umumnya digunakan kalimat unik.

Bahasa prokem adalah kata nonstandar, diatur dengan cara yang unik fungsi yang digunakan dalam percakapan sangat kuat dan cerdas. Terkadang, bahasa yang muncul dari pengucapan berbeda jauh dengan bahasa prokem. Bahasa prokem sebenarnya tidak hanya ada di kalangan masyarakat terpelajar, tetapi juga di semua lapisan masyarakat. Latar belakang dan lingkungan yang berbeda, bahasa yang mereka gunakan juga berbeda atau berubah-ubah, dan perubahan atau mutasinya biasanya sangat berbeda jauh dari sebelumnya. Untuk situasi formal akan digunakan tipe bahasa yang disebut tipe standar, sedangkan untuk situasi informal akan digunakan tipe nonstandar.

Bahasa prokem berfungsi sebagai ekspresi selera pengguna atau para remaja. Penggunaan bahasa prokem juga dapat digunakan ketika remaja ingin mendeklarasikan diri sebagai anggota kelompok komunitas atau kelompok masyarakat lainnya. Kehadiran bahasa prokem dianggap masuk akal karena disetujui dengan kebutuhan pengembangan kesadaran remaja. Bentuk tersebut sangat sering digunakan untuk. Singkatan atau akronim adalah kurangnya kata atau digabungkan dari suku kata yang berbeda. Perbedaan antara singkatan dan akronim adalah bentuk kata yang disingkat, sedangkan akronim diucapkan sebagai suku kata. Singkatan memiliki sub-kategori, yaitu singkatan, akronim. Penggunaan singkatan tidak hanya digunakan oleh remaja, masyarakat umum sering menyingkat kata ketika dikomunikasikan dalam kehidupan 
sehari-hari. Misalnya, kata bawa perasaan disingkat baper dan males gerak disingkat mager.

Bahasa ini memiliki banyak ragam bahasa. Keragaman bahasa didasarkan pada topik pembahasan, hubungan antara penutur, lawan bicara, penutur, dan bahasa penutur sesuai dengan penggunaan yang berbeda. Penggunaan varian atau varian bahasa melibatkan banyak faktor, seperti usia, tingkat pendidikan, jenis kelamin, pekerjaan, tingkat aristokrasi, status sosial ekonomi, dan lain-lain. Berdasarkan usia dapat dilihat adanya perbedaan variasi bahasa yang digunakan oleh remaja.

Bahasa prokem tidak hanya muncul baru-baru ini, tetapi sudah ada sejak lama. Awalnya, bahasa itu sering disebut gaul. Bahasa prokem sebelum majunya zaman awalnya hanya digunakan oleh para preman yang hidupnya dekat dengan kejahatan dan kekerasan. Banyak istilah baru diciptakan untuk membuat orang lain tidak mungkin memahami apa yang dikatakan. Seringnya menggunakan kata-kata di berbagai tempat, istilah tersebut akhirnya menjadi perbincangan sehari-hari. Remaja cenderung menggunakan kata-kata untuk berkomunikasi dengan teman sebaya atau anggota kelompoknya. Kata-kata yang mereka gunakan kreatif dan memiliki nilai sosial tertentu, seperti I, loe, boring, garing, lebay, dan kata lain yang biasa digunakan oleh remaja.

Kata- kata dalam bahasa prokem tidak memiliki standar definitif karena itu tergantung pada suasana hati seseorang yang menghasilkan kata. Meskipun bahasa prokem memiliki tulisan standar yang sangat berbeda dari orang Indonesia, orang yang sering menggunakan bahasa prokem dengan cepat memahami apa yang dikatakan lawan. Pada dasarnya bahasa prokem tidak digunakan dalam topik formal seperti pidato, ujian, rapat, menulis artikel, menulis dokumen, dan sebagainya. Harus diakui bahwa munculnya bahasa baru, jelas, akan mempengaruhi perkembangan dibidang linguistik, pengaruh positif atau negatif, tanpa kecuali. Melihat berbagai gaya bahasa yang digunakan oleh remaja, ini dapat ditentukan bahwa kebanyakan orang, terutama orang tua, tidak memahami arti dari kata pokem yang digunakan oleh remaja. Sangat menarik untuk dipelajari lebih lanjut dengan menganalisis berbagai bahasa prokem yang sering digunakan oleh remaja. Berdasarkan fenomena sebelumnya, peneliti tertarik untuk memilih judul "Analisis Penggunaan Bahasa Prokem Pada Remaja di Desa Kutanegara Kabupaten Karawang"

\section{B. METODE PENELITIAN}


Metode penelitian yang digunakan adalah metode deskriptif kualitatif. Alasan peneliti menggunakan metode deskriptif kualitatif karena data yang diperoleh peneliti berasal dari penelitian observasi dan wawancara. Penelitian kualitatif yang dilakukan untuk menggali, memahami, dan menggambarkan suatu obyek penelitian dengan cara deskriptif berupa kata-kata dan bahasa (Moeleng, 2002:3). Metode penelitian deskriptif kualitatif ini didasarkan pada fakta keseluruhan. Data dalam penelitian ini yaitu ujaran berkaitan dengan Bahasa prokem di di Desa Kutanegara Kabupaten Karawang. Sumber data dalam penelitian in yaitu remaja yang menuturkan Bahasa prokem di Desa Kutanegara Kabupaten Karawang. Analisis hasil data penelitian dapat berasal dari data lapangan. Teknik pengumpulan data yang digunakan penelitian ini adalah teknik observasi, wawancara, dokumentasi, dan pustaka. Teknik analisis data dengan langkahlangkah reduksi data, interpretasi data, dan menyimpulkan hasil penelitian tentang penggunaan bahasa prokem di Desa Kutanegara Kabupaten Karawang.

\section{HASIL PENELITIAN DAN PEMBAHASAN}

Berdasarkan hasil penelitian dengan cara analisis data, hasil observasi, wawancara, kajia pustakan, dan dokumentasi penggunaan bahasa prokem pada remaja di Desa Kutanegara Kabupaten Karawang menunjukkan bahwa bahasa prokem sudah sangat biasa digunakan oleh para remaja, terdapat faktor-faktor penggunaan bahasa prokem pada remaja, dan penggunaan bahasa prokem mengakibatkan dampak positif dan negatif.

Pemerolehan data didapatkan dengan cara mewawancarai para remaja. Hal tersebut dilakukan agar peneliti dapat menganalisis bahasa prokem yang ada di daerah tersebut.

Tabel 4.1 Penggunaan Bahasa Prokem Remaja

\begin{tabular}{|l|l|l|}
\hline No & Bahasa Prokem & \multicolumn{1}{c|}{ Arti/Makna } \\
\hline 1 & Alay & Anak layangan yang berpenampilan norak \\
\hline 2 & Baper & Bawa Perasaan \\
\hline 3 & Boring & Bosan \\
\hline 4 & Garing & Tidak lucu \\
\hline 5 & Kuy & Yuk \\
\hline 6 & Kane & Enak \\
\hline 7 & Kaciduk & ketahuan \\
\hline 8 & DL & Derita loe \\
\hline 9 & Kepo & Ingin tahu \\
\hline 10 & Rempong & Repot \\
\hline 11 & Woles & Santai \\
\hline 12 & Keleus & Kali \\
\hline
\end{tabular}


Lingua Rima: Jurnal Pendidikan Bahasa dan Sastra Indonesia

Vol. 11 No. 1 Januari 2022

http://jurnal.umt.ac.id/index.php//grm

\begin{tabular}{|l|l|l|}
\hline 13 & Anjay & Anjing \\
\hline 14 & Ngegas & Berbicara dengan nada tinggi. \\
\hline 15 & Bikes & Bikin kesel \\
\hline 16 & Bingit & Banget \\
\hline 17 & PW & Posisi Wenak \\
\hline 18 & Caper & Cari perhatian \\
\hline 19 & Gaje & Gak jelas \\
\hline 20 & Anjir & Anjing \\
\hline 21 & Curcol & Curhat Colongan \\
\hline 22 & Modus & Modal Dusta \\
\hline 23 & PHP & Pemberi Harapan Palsu \\
\hline 24 & Kemal & Kepo Maksimal \\
\hline 25 & Pecah & Seru \\
\hline
\end{tabular}

Dalam hasil wawancara remaja tersebut terdapat hasil data ragam bahasa prokem yang diperoleh dari remaja Desa Kutanegara Kabupaten Karawang. Untuk lebih jelasnya dapat dilihat dari analisis data berikut ini:

1) Alay

Alay merujuk pada arti/makna anak layangan yang berpenampilan norak. Maksud dari arti/makna tersebut adalah suatu penampilan atau tingkah laku seseorang yang tidak sesuai dengan keadaan. Misalnya, cara berpakaian yang warnanya tidak selaras. Contoh penggunaan kata alay yang digunakan oleh para remaja desa Kutanegara kabupaten Karawang dalam kehidupan sehari-hari:

Tabel 4.2 Penggunaan Kata Alay

\begin{tabular}{|l|l|l|}
\hline No & Ujaran & Terjemah \\
\hline 1 & Ih, gayana meni alay pisan. & Ih, gayanya alay banget. \\
\hline 2 & $\begin{array}{l}\text { Plis, atuda, ulah alay tibang } \\
\text { meli buku oge. }\end{array}$ & Plis, deh, jangan alay cuma beli buku. \\
\hline 3 & $\begin{array}{l}\text { Ih, maneh alay pisan make } \\
\text { sapatu eta. }\end{array}$ & Ih, kamu alay banget pakai sepatu itu. \\
\hline
\end{tabular}

Makna dari contoh penggunaan kata alay itu mempunyai berbagai makna tergantung konteks yang dibicarakan. Seperti pada contoh ujaran: nomor 1) alay yang dikatakan oleh penutur bermaksud untuk mengomentari gaya berpakaian mitra tutur. 2) alay yang dimaksud oleh penutur untuk memprotes mitra tutur karena bersikap berlebihan terhadap tindakan yang dilakukan oleh mitra tutur. 3) maksud kata alay yang dilontarkan oleh penutur kepada mitra tutur karena sepatu yang digunakan terlihat norak.

2) Baper 
Baper merajuk pada arti/makna bawa perasaan. Maksud dari kata tersebut adalah keadaan seseorang yang mudah terpengaruh dengan suasana. Misalnya, ketika melihat orang menangis menajdi ikut sedih atau merasakan apa yang dirasakan orang lain. Berikut contoh penggunaan kata baper yang biasa digunakan dalam berkomunikasi oleh remaja desa Kutanegara kabupaten Karawang:

Tabel 4.3. Penggunaan Kata Baper

\begin{tabular}{|l|l|l|}
\hline No & \multicolumn{1}{|c|}{ Ujaran } & \multicolumn{1}{|c|}{ Terjemah } \\
\hline 1 & $\begin{array}{l}\text { Maneh mere kembang? urang } \\
\text { jadi baper. }\end{array}$ & Kamu ngasih bunga? Aku jadi baper. \\
\hline 2 & $\begin{array}{l}\text { Si Siti dibere motor } k u \\
\text { kabogohna? Urang jadi ngilu } \\
\text { baper. }\end{array}$ & $\begin{array}{l}\text { Si Siti, dikasih motor sama pacarnya? } \\
\text { Aku jadi ikut baper. }\end{array}$ \\
\hline 3 & $\begin{array}{l}\text { Urang jadi ngilu baper ningali } \\
\text { kebo labuh. }\end{array}$ & $\begin{array}{l}\text { Aku jadi ikut baper lihat kerbau } \\
\text { terjatuh. }\end{array}$ \\
\hline
\end{tabular}

Makna ujaran penggunaan kata baper yang digunakan remaja desa Kutanegara kabupaten Karawang yaitu: 1) "Kamu ngasih bunga? Aku jadi baper". Makna baper dalam konteks tersebut pembicaan tersebut merujuk kepada perasaan bahagia dan terharu. 2) "Si Siti, dikasih motor sama pacarnya? Aku jadi ikut baper". Makna pembicaraan tersebut yaitu penutur baper karena ikut bahagia atas kejadian yang dialami oleh Siti. 3) "Aku jadi ikut baper lihat kerbau terjatuh". Konteks baper yang dimaksud dalam pembicaraan tersebut yaitu penutur merasakan kesedihan karena kerbau terjatuh.

3) Boring

Kata boring berasal dari bahasa Inggris termasuk ke jenis kata sifat atau adjectiva. Boring merajuk pada arti/makna bosan. Maksud dari kata tersebut adalah keadaan yang dihadapi seseorang yang bosan terhadap sesuatu. Kata boring ini biasanya digunakan oleh remaja-remaja di kota. Semakin pesatnya dunia teknolgi bahasa yang biasa digunakan oleh orang-orang kota sudah terbiasa digunakan juga oleh orang-orang di desa khususnya remaja. Berikut contoh penggunaan kata boring yang biasa digunakan dalam berkomunikasi oleh remaja desa Kutanegara kabupaten Karawang:

Tabel 4.4. Penggunaan Kata Boring

\begin{tabular}{|l|l|l|}
\hline No & \multicolumn{1}{|c|}{ Ujaran } & \multicolumn{1}{c|}{ Terjemah } \\
\hline 1 & $\begin{array}{l}\text { Boring pisan didieu meni } \\
\text { tiiseun. }\end{array}$ & Boring banget di sini sangat sepi. \\
\hline
\end{tabular}


Lingua Rima: Jurnal Pendidikan Bahasa dan Sastra Indonesia

Vol. 11 No. 1 Januari 2022

http://jurnal.umt.ac.id/index.php//grm

\begin{tabular}{|l|l|l|}
\hline 2 & Ulin yu, boring icing didieu wae. & Main yuk, boring diem di sini mulu. \\
\hline 3 & Euweuh gawe boring pisan. & Gak ada kerjaan boring banget. \\
\hline
\end{tabular}

Penggunaan kata boring mempunyai banyak makna tergantung konteks pembicaraan penutur dan mitra tutur. Seperti contoh ujaran berikut: 1) "Boring pisan didieu meni tiiseun". Boring yang dimaksud adalah perasaan bosan terhadap suatu suasana. 2) "Ulin yu, boring icing didieu wae". Boring yang dimaksud penutur adalah perasaan bosan terhadap keadaan. 3) "Euweuh gawe boring pisan". Sama halnya dengan contoh ujaran nomor 2 yaitu boring terhadap suatu keadaan.

\section{4) Garing}

Kata garing berasal dari bahasa Sunda yang artinya kriuk, namun karena banyak yang menggunakan kata garing di berbagai daerah sehingga digunakan oleh kebanyakan orang.Garing merujuk pada arti/makna tidak lucu. Maksud dari kata tersebut adalah respon seseorang terhadap lawan bicara yang sedang melucu tapi dianggap tidak lucu. Kata garing sudah sering digunakan dunia Stand Up Comedy untuk merespon pembicaraan mau pun menceritakan suatu hal. Berikut contoh penggunaan kata garing yang biasa digunakan dalam berkomunikasi oleh remaja desa Kutanegara kabupaten Karawang:

\section{Tabel 4.5. Penggunaan Kata Garing}

\begin{tabular}{|l|l|l|}
\hline No & \multicolumn{1}{|c|}{ Ujaran } & \multicolumn{1}{c|}{ Terjemah } \\
\hline 1 & $\begin{array}{l}\text { Hayu, geura balik acara Stand } \\
\text { Up Comedy na garing. }\end{array}$ & $\begin{array}{l}\text { Ayo, pulang acara Stand Up Comedy- } \\
\text { nya garing. }\end{array}$ \\
\hline 2 & Naon sih, garing pisan. & Apa sih, garing banget. \\
\hline
\end{tabular}

Makna ujaran penggunaan kata garing yang digunakan remaja desa Kutanegara kabupaten Karawang yaitu: 1) "Hayu, geura balik acara Stand Up Comedy na garing”. Makna garing yang diujarkan oleh penutur yaitu acara yang ditonton Stand Up Comedy tidak lucu atau garing. 2) "Naon sih, garing pisan”. Makan garing tersebut biasanya digunakan oleh mitra tutur terhadap penutur yang leluconnya tidak lucu atau garing.

5) Kuy

Kuy merupakan kata ajakan yang penulisan dibalik. Kuy merajuk pada arti/makna yuk. Kata tersebut biasanya digunakan untuk mengajak seseorang berkegiatan. Kata yang dibolak-balik dalam bahasa prokem adalah hal yang biasa 
Lingua Rima: Jurnal Pendidikan Bahasa dan Sastra Indonesia

Vol. 11 No. 1 Januari 2022

http://jurnal.umt.ac.id/index.php//grm

walaupun kata-katanya dibolak-balik bisa dimengerti oleh remaja atau anak gaul. Berikut contoh penggunaan kata kuy yang biasa digunakan dalam berkomunikasi oleh remaja desa Kutanegara kabupaten Karawang:

Tabel 4.6. Penggunaan Kata Kuy

\begin{tabular}{|l|l|l|}
\hline No & Ujaran & Terjemah \\
\hline 1 & $\begin{array}{l}\text { Kuy, meli seblak } \\
\text { ka warung. }\end{array}$ & Kuy, beli seblak ke warung. \\
\hline 2 & $\begin{array}{l}\text { Kuy, ulin ka } \\
\text { Bandung }\end{array}$ & Kuy, main ke Bandung. \\
\hline
\end{tabular}

Contoh ujaran kata kuy yang dikatakan oleh penutur terhadap mitra tutur yaitu mengajak: 1) membeli seblak. 2) main ke Bandung. Kata kuy hanya mempunyai satu makna yaitu mengajak. Kata kuy tidak seperti bahasa prokem lainnya yang mempunyai banyak makna.

6) Kane

Kata kane merupakan kata yang dibalik dari kata enak. Kane merajuk pada arti/makna enak. Kata tersebut biasanya digunakan untuk kenyamanan terhadap sesuatu. Kata kane awalnya terkenal di Twitter sehingga dipakai di kehidupan sehari-hari oleh remaja atau anak gaul. Berikut contoh penggunaan kata kane yang biasa digunakan dalam berkomunikasi oleh remaja desa Kutanegara kabupaten Karawang:

Tabel 7. Penggunaan Kata Kane

\begin{tabular}{|l|l|l|}
\hline No & Ujaran & Terjemah \\
\hline 1 & $\begin{array}{l}\text { Kane pisan jakeur di reungeu } \\
\text { laguna euy. }\end{array}$ & Kane banget lagunya buat didengar. \\
\hline 2 & Kane pisan tempatna iyuh. & Kane banget tempatnya adem. \\
\hline
\end{tabular}

Makna ujaran penggunaan kata kane yang digunakan remaja desa Kutanegara kecamatan Ciampel yaitu: 1) “Kane pisan jakeur di reungeu laguna euy”. Kane yang dimaksud oleh penutur adalah ketertarikan terhadap suara musik. 2) "Kane pisan tempatna iyuh". Kane yang dimaksud adalah kenyamantan terhadap suatu tempat.

7) Kaciduk

Kata tersebut merajuk pada arti/makna ketahuan atau tertangkap biasanya digunakan pada saat ada kejadian ketahuan yang tidak direncanakan. Kata kaciduk ini biasanya digunakan ketika ada orang yang tertangkap basah atas tindakan yang 
Lingua Rima: Jurnal Pendidikan Bahasa dan Sastra Indonesia

Vol. 11 No. 1 Januari 2022

http://jurnal.umt.ac.id/index.php/lgrm

dilakukan. Contoh penggunaan kata kaciduk yang biasa digunakan dalam berkomunikasi oleh remaja desa Kutanegara kabupaten Karawang:

Tabel 4.8. Penggunaan Kata Terciduk

\begin{tabular}{|l|l|l|}
\hline No & \multicolumn{1}{|c|}{ Ujaran } & \multicolumn{1}{c|}{ Terjemah } \\
\hline 1 & $\begin{array}{l}\text { Kamari anu maling hayam } \\
\text { kaciduk di pasar. }\end{array}$ & $\begin{array}{l}\text { Kemarin yang maling ayam terciduk di } \\
\text { pasar. }\end{array}$ \\
\hline 2 & Maneh kaciduk teu puasa & Kamu terciduk ga puasa. \\
\hline
\end{tabular}

Makna ujaran penggunaan kata kaciduk yang digunakan remaja desa Kutanegara kabupaten Karawang yaitu: 1) "Kamari anu maling hayam kaciduk di pasar". Makna kaciduk pada ujaran tersebut yaitu tertangkap terhadap tindakan yang dilakukan. 2). Maneh kaciduk teu puasa”. Makna kaciduk dalam ujaran tersebut mitra tutur ketahuan melakukan tindakan yang tidak diduga oleh penutur.

8) $D L$

Pada kata $D L$ merajuk pada arti/makna derita loe. Misalnya pada saat remaja mengalami kesulitan atau dalam masalah sesama remaja sering mengatakan derita loe artinya itu hanya derita saja. Kata $D L$ awalnya terkenal di kalangan remaja daerah Jakarta. Seiring berjalannya waktu kata $D L$ semakin banyak dikenal dan masuk ke pedesaan sehingga di daerah pedesaan kata $D L$ sudah tidak asing. Contoh penggunaan kata $D L$ yang biasa digunakan dalam berkomunikasi oleh remaja desa Kutanegara kabupaten Karawang:

Tabel 4.9. Penggunaan Kata $D L$

\begin{tabular}{|l|l|l|}
\hline No & Ujaran & Terjemah \\
\hline 1 & $\begin{array}{l}\text { Maneh labuh? Etaman DL, } \\
\text { masalah dijieun sorangan. }\end{array}$ & $\begin{array}{l}\text { Kamu jatuh? Itu udah derita loe, masalah } \\
\text { dibuat sendiri. }\end{array}$ \\
\hline
\end{tabular}

Makna ujaran contoh kata DL tersebut penutur mengatakan kepada mitra tutur bahwa kejadiaan menimpanya diakibatkan oleh perbuatan sendiri.

9) Kepo

Kata kepo kepanjangan dari Knowing Every Particular Object. Kata kepo merujuk pada arti/makna rasa ingin tahu yang cenderung membuat penasaran. Contoh penggunaan kata kepo yang biasa digunakan dalam berkomunikasi oleh remaja desa Kutanegara kabupaten Karawang: 
Lingua Rima: Jurnal Pendidikan Bahasa dan Sastra Indonesia

Vol. 11 No. 1 Januari 2022

http://jurnal.umt.ac.id/index.php/lgrm

Tabel 4.10. Penggunaan Kata Kepo

\begin{tabular}{|l|l|l|}
\hline No & \multicolumn{1}{|c|}{ Ujaran } & \multicolumn{1}{c|}{ Terjemah } \\
\hline 1 & $\begin{array}{l}\text { Naon sih, kepo pisan lain } \\
\text { urusan maneh oge. }\end{array}$ & $\begin{array}{l}\text { Apa sih, kepo banget bukan urusan } \\
\text { kamu. }\end{array}$ \\
\hline
\end{tabular}

Makna contoh ujaran kata kepo adalah bentuk tidak nyaman atau protesnya penutur terhadap mitra tutur yang selalu ingin tahu masalah orang lain.

10) Rempong

Rempong merujuk pada arti/ makna repot atau ribet. Maksud tersebut ditujukan dalam berpenampilan, tingkah laku, dan lain-lain. Kata rempong sering digunakan oleh para remaja.

Tabel 4.11. Penggunaan Kata Rempong

\begin{tabular}{|l|l|l|}
\hline No & \multicolumn{1}{|c|}{ Ujaran } & \multicolumn{1}{c|}{ Terjemah } \\
\hline 1 & $\begin{array}{l}\text { Rempong pisan euy mamawa } \\
\text { buku meni loba. }\end{array}$ & $\begin{array}{l}\text { Ribet banget bawa buku } \\
\text { kebanyakan. }\end{array}$ \\
\hline 2 & Rempong pisan euy bajuna. & Ribet banget bajunya. \\
\hline
\end{tabular}

Makna ujaran penggunaan kata rempong yang digunakan remaja desa Kutanegara kecamatan Ciampel yaitu: 1) "Rempong pisan euy mamawa buku meni loba”. Rempong yang dimaksud adalah ketika berlebihan dalam membawa sesuatu. 2) “Rempong pisan euy bajuna.". rempong yang dimaksud dalam contoh tersebut adalah ribet dalam berpakaian.

11) Woles

Woles merujuk pada arti/makna santai. Kata woles biasanya digunakn oleh para remaja ketika dalam keadaan tergesa-gesa atau pada saat ada perseteruan mau pun perbedaan pendapat. Contoh penggunaan kata woles yang biasa digunakan dalam berkomunikasi oleh remaja desa Kutanegara kabupaten Karawang:

Tabel 4.12. Penggunaan Kata Woles

\begin{tabular}{|l|c|c|}
\hline No & \multicolumn{1}{|c|}{ Ujaran } & Terjemah \\
\hline 1 & Woles atuh A ek kamana sih? & Santai dong, Kak mau ke mana sih? . \\
\hline
\end{tabular}

Makna contoh ujaran tersebut penutur bermaksud untuk mencairkan suasana agar mitra tutur tidak tergesa-gesa.

12) Keleus

Keleus merujuk pada arti/makna kali. Kata keleus yang biasanya digunakan oleh para remaja sebagai kata keterangan. Contoh penggunaan kata keleus yang biasa digunakan dalam berkomunikasi oleh remaja desa Kutanegara kabupaten Karawang: 
Lingua Rima: Jurnal Pendidikan Bahasa dan Sastra Indonesia

Vol. 11 No. 1 Januari 2022

http://jurnal.umt.ac.id/index.php//grm

Tabel 4.13. Penggunaan Kata Keleus

\begin{tabular}{|l|l|l|}
\hline No & Ujaran & Terjemah \\
\hline 1 & Biasa weh atuh keleus. & Biasa aja kali. \\
\hline
\end{tabular}

Kata keleus tidak memiliki banyak makna sehingga kata keleus di desa Kutanegara kabupaten Karawang tidak sering digunakan di kalangan remaja.

\section{3) Anjay}

Anjay merujuk pada arti/makna anjing. Kata anjay digunakan untuk menyamarkan kata anjing yang dilihat bermakna kasar. Kata ini merupakan kreasi bahasa anak muda pada generasi milenial yang muncul baru-baru ini. Contoh penggunaan kata anjay yang biasa digunakan dalam berkomunikasi oleh remaja desa Kutanegara kabupaten Karawang:

Tabel 4.14. Penggunaan Kata Anjay

\begin{tabular}{|l|l|l|}
\hline No & \multicolumn{1}{|c|}{ Ujaran } & \multicolumn{1}{c|}{ Terjemah } \\
\hline 1 & Anjay, eta motor alus pisan. & Anjay, itu motor keren banget. \\
\hline 2 & $\begin{array}{l}\text { Anjay, maneh geus boga } \\
\text { kabogoh? }\end{array}$ & Anjay, kamu udah punya pacar? \\
\hline
\end{tabular}

Contoh penggunaan kata anjay: 1) “Anjay, eta motor alus pisan”. Makna anjay dalam ujaran yang diungkapkan oleh penutur adalah perasaan kagum terhadap motor bagus. 2) “Anjay, maneh geus boga kabogoh?” makna anjay tersebut adalah penutur menyampaikan pertanyaan kepada mitra tutur untuk memastikan kebenaran apakah mitra tutur sudah punya pacara atau belum.

\section{4) Ngegas}

Ngegas merujuk pada arti/makna berbicara menggunakan nada tinggi. Dalam bahasa gaul kata ini sering digunakan ketika reaksi seseorang yang tiba-tiba emosi baik dalam berbicara mau pun ketikan. Berikut contoh penggunaan kata ngegas:

Tabel 4.15. Penggunaan Kata Ngegas

\begin{tabular}{|l|l|l|}
\hline No & \multicolumn{1}{|c|}{ Ujaran } & \multicolumn{1}{c|}{ Terjemah } \\
\hline 1 & $\begin{array}{l}\text { Ulah ngegas atuh } \\
\text { ngomongna. }\end{array}$ & Jangan ngegas dong ngomongnya. \\
\hline
\end{tabular}

\section{5) Bikes}

Bikes merujuk pada arti/makna bikin kesel. Kata tersebut biasanya digunaan untuk bercandanya para remaja. Misalnya remaja yang sedang berbicara dan lawan 
Lingua Rima: Jurnal Pendidikan Bahasa dan Sastra Indonesia

Vol. 11 No. 1 Januari 2022

http://jurnal.umt.ac.id/index.php//grm

bicaranya tidak mengerti sehingga remaja tersebut merespon kembali dengan berkata bikes. Berikut contoh penggunan kata bikes:

Tabel 4.16. Penggunaan Kata Bikes

\begin{tabular}{|l|l|l|}
\hline No & \multicolumn{1}{|c|}{ Ujaran } & \multicolumn{1}{|c|}{ Terjemah } \\
\hline 1 & $\begin{array}{l}\text { Maneh mah bikes pisan } \\
\text { teu ngarti-ngarti. }\end{array}$ & $\begin{array}{l}\text { Kamu tuh bikes banget ga ngerti- } \\
\text { ngerti. }\end{array}$ \\
\hline
\end{tabular}

16) Bingit

Bingit merujuk pada arti/makna banget. Kata bingit biasanya digunakan antusiasme terhadap sesuatu. Kata bingit keluar baru-baru ini disebarluaskan oleh kaum milenial. Berikut contoh penggunaan kata bingit :

Tabel 4.17. Penggunaan Kata Bingit

\begin{tabular}{|l|l|l|}
\hline No & \multicolumn{1}{|c|}{ Ujaran } & \multicolumn{1}{c|}{ Terjemah } \\
\hline 1 & $\begin{array}{l}\text { Ngeunah bingit ieu } \\
\text { hayam goreng teh. }\end{array}$ & Enak bingit ini ayam goreng. \\
\hline
\end{tabular}

Penggunaan kata bingit mempunyai banyak makna tergantung konteks yang dibicarakan. Kata bingit bisa merujuk kemana pun seperti makanan, tempat, pakaian, benda mati, dan lain-lain.

17) $P W$

$P W$ merujuk pada arti/makna posisi wenak. $P W$ merupakan kata singkatan dari posisi wenak dan gabungan dari bahasa Indonesia dan Jawa. Kata ini menjadi pengganti kata santai atau nyaman. Contohnya ketika para remaja sudah malas untuk berpindah tempat sehingga mengatakan sudah $P W$.

Tabel 4.18. Penggunaan Kata $P W$

\begin{tabular}{|l|l|l|}
\hline No & \multicolumn{1}{|c|}{ Ujaran } & \multicolumn{1}{|c|}{ Terjemah } \\
\hline 1 & $\begin{array}{l}\text { A: Pindah heula bangkuna ka } \\
\text { belah ditu. } \\
\text { B: Dih, urang geus } P W .\end{array}$ & A: Pindahin dulu bangkunya ke sana. \\
B: Dih, aku udah PW.
\end{tabular}

\section{8) Caper}

Kata caper merujuk pada arti/makna cari perhatian. Kata tersebut biasanya digunakan untuk mengkritik orang atas perbuatannya. Kata caper ini merupakan 
Lingua Rima: Jurnal Pendidikan Bahasa dan Sastra Indonesia

Vol. 11 No. 1 Januari 2022

http://jurnal.umt.ac.id/index.php//grm

bentuk respon negatif terhadap perbuatan seseorang. Berikut contoh penggunaan kata caper:

Tabel 4.19. Penggunaan Kata Caper

\begin{tabular}{|l|l|l|}
\hline No & \multicolumn{1}{|c|}{ Ujaran } & \multicolumn{1}{c|}{ Terjemah } \\
\hline 1 & $\begin{array}{l}\text { Naon sih maneh teh caper } \\
\text { pisan. }\end{array}$ & Apasih, kamu caper banget. \\
\hline
\end{tabular}

\section{9) Gaje}

Gaje merujuk pada arti/makna gak jelas. Kata tersebut biasanya digunakan untuk merespon seseorang yang berbicara tidak dapat dipahami atau tidak nyambung. Kata tersebut juga digunakan pada saat keadaan tidak jelas dan sulit dipahami. Berikut contoh penggunaan kata gaje:

Tabel 4.20. Penggunaan Kata Gaje

\begin{tabular}{|l|l|l|}
\hline No & \multicolumn{1}{|c|}{ Ujaran } & \multicolumn{1}{c|}{ Terjemah } \\
\hline 1 & $\begin{array}{l}\text { Naon sih gaje pisan maneh teh } \\
\text { urang teu ngaerti. }\end{array}$ & $\begin{array}{l}\text { Apasih, caper banget kamu tuh aku gak } \\
\text { ngerti. }\end{array}$ \\
\hline 2 & Ih, tempatna gaje pisan. & Ih, tempatnya gaje banget. \\
\hline
\end{tabular}

Makna gaje bisa terjadi ketika seseorang tidak paham akan pembicaraan seseorang dan tidak paham akan keadaan suatu tempat. Seperti contoh ujaran: 1) "Naon sih gaje pisan maneh teh urang teu ngaerti". Makna gaje tersebut ditujukan terhadap seseorang yang tidak paham alur pembicaraan. 2) "Ih, tempatna gaje pisan”. Makna gaje tersebut ditujukan terhadap ketidakpahaman suatu keadaan.

20) Anjir

Anjir merujuk pada arti/makna anjing. Sama halnya dengan kata anjay kata anjing dipelesetkan menjadi anjing agar tidak terlalu kasar. Kata anjir ini biasanya digunakan ketika merespon hal yang mengagumkan. Plesetan kata anjing sangat banyak bukan hanya anjir dan anjay saja seperti, anjrit, anjrot, ajig, anj, dan lainlain. Berikut contoh penggunaan kata anjir:

Tabel 4.21. Penggunaan Kata Anjir

\begin{tabular}{|l|l|l|}
\hline No & \multicolumn{1}{|c|}{ Ujaran } & \multicolumn{1}{c|}{ Terjemah } \\
\hline 1 & Anjir, ieu imah alus pisan. & Anjir, ini rumah bagus banget. \\
\hline 2 & Anjir, jalanan meni butut. & Anjir, jalannya jelek banget. \\
\hline
\end{tabular}

21) Curcol 
Lingua Rima: Jurnal Pendidikan Bahasa dan Sastra Indonesia

Vol. 11 No. 1 Januari 2022

http://jurnal.umt.ac.id/index.php//grm

Curcol merujuk pada curhat colongan. Kata ini biasanya sering digunakan oleh perempuan untuk bergosip. Curcol ini dilakukan bersamaan dengan cerita hal lain yang tidak berhubungan secara langsung dengan topik pembicaraan. Contoh penggunaan kata curcol:

Tabel 4.22. Penggunaan Kata Curcol

\begin{tabular}{|l|l|l|}
\hline No & \multicolumn{1}{|c|}{ Ujaran } & \multicolumn{1}{c|}{ Terjemah } \\
\hline 1 & A: Ih, urang sedih pisan. & A: Ih, aku sedih banget. \\
& B: Kunaon? Curcol yu. & B: Kenapa? Curcol yuk. \\
\hline
\end{tabular}

\section{2) Modus}

Kata modus ini merujuk pada arti/makna modal dusta. Kata ini biasanya digunakan untuk merespon seseorang yang memiliki niat lain dibalik pembicaraanya karena omongannya selalu bohong. Contoh penggunaan kata modus:

Tabel 4.23. Penggunaan Kata Modus

\begin{tabular}{|l|l|l|}
\hline No & \multicolumn{1}{|c|}{ Ujaran } & \multicolumn{1}{c|}{ Terjemah } \\
\hline 1 & A: Neng, ajarkeun Aa & A: Neng, ajarin kakak pelajaran ini \\
& palajaran ieu atuh, can ngarti. & dong, belum ngerti. \\
& B: Naon sih bohong pisan, & B: Apa sih bohong banget, nilai kamu \\
& nilai maneh leuwih gede oge. & lebih gede. Modus, kamu. \\
& Modus, maneh. & \\
\hline
\end{tabular}

23) PHP

Kata PHP merupan singkatan dari Pemberi Harapan Palsu. Kata ini biasa digunakan untuk orang-orang yang memberkan harapan palsu. Kata ini juga berfungsi untuk mengutarakan isi hati seseorang ketika sudah diberi harapan palsu. Contoh penggunaan kata $P H P$ :

Tabel 4.24. Penggunaan Kata $P H P$

\begin{tabular}{|l|l|l|}
\hline No & Ujaran & Terjemah \\
\hline 1 & A: Isukan meli seblak yu. & A: Besok beli seblak yuk. \\
& B: Ah manehmah PHP, kamari & B: Ah kamu PHP, kemarin aja ga jadi \\
& ge teu jadi meli buku. & beli buku. \\
\hline
\end{tabular}

\section{4) Kemal}

Kemal artinya kepo maksimal. Kata ini biasanya digunakan untuk mengomentari orang yang ingin tahu berlebihan terhadap sesuatu yang bukan urusannya. Berikut contoh penggunaan kata kemal: 
Lingua Rima: Jurnal Pendidikan Bahasa dan Sastra Indonesia

Vol. 11 No. 1 Januari 2022

http://jurnal.umt.ac.id/index.php//grm

Tabel 4.25. Penggunaan Kata Kemal

\begin{tabular}{|l|l|l|}
\hline No & Ujaran & Terjemah \\
\hline 1 & A: Maneh geus jadi kabogoh si & A: Kamu udah jadian sama si A? \\
& A? Iraha jadina? Dimana & Kapan jadiannya? Dimana jadiannya? \\
& jadina? & B: Dih, kamu kemal banget. \\
& B: Dih, maneh kemal pisan. & \\
\hline
\end{tabular}

\section{5) Pecah}

Kata pecah ini merujuk makna seru. Makna pecah yang dimaksud bukan barang yang hancur namun pecah yang dimaksud adalah hal-hal yang dinilai keren, mengagumkan, dan fantastis. Kata ini digunakan ketika dalam suatu kejadian ada hal yang mengagumkan dan menyenangkan. Berikut contoh penggunaan kata pecah:

Tabel 4.26. Penggunaan Kata Pecah

\begin{tabular}{|l|l|l|}
\hline No & \multicolumn{1}{|c|}{ Ujaran } & Terjemah \\
\hline 1 & Pecah pisan tadi acarana. & Pecah banget acaranya. \\
\hline
\end{tabular}

Setelah melakukan penelitian dengan mewawancarai para remaja di Desa Kutanegara Kabupaten Karawang terdapat 25 kata bahasa prokem yang biasa digunakan oleh para remaja di Desa Kutanegara Kabupaten Karawang. Bahasa prokem tersebut dipahami semua remaja karena pada saat komunikasi menggunakan kata-kata prokem tersebut.

2. Faktor-faktor Penggunaan Bahasa Prokem

Berdasarkan hasil penelitian yang dilakukan di Desa Kutanegara Kabupaten Karawang penggunaan bahasa prokem pada remaja mempunyai faktor-faktor pemicu, faktor-faktor tersebut yaitu:

1) Keberadaan bahasa prokem ditunjukkan dengan menjamurnya internet dan situs jejaring sosial. Dimana bahasa memiliki pengaruh yang signifikan terhadap perkembangan perkembangan bahasa. Penikmat situs jejaring sosial (kebanyakan remaja) menjadi agen komunikasi komunikasi. Orang yang berbicara bahasa ini akan dilihat oleh ribuan anak muda lainnya dan ditiru oleh mereka.

2) Lingkungan sekitar. Biasanya remaja menarik perhatian dari percakapan orang dewasa dan teman sebaya di sekitarnya. 
3) Media cetak, seperti bahasa di majalah, koran atau koran. Selain itu, produksi karya sastra remaja (seperti cerpen atau novel) biasanya menggunakan bahasa.

4) Perkembangan dan pengaruh zaman atau modernisasi, segala sesuatu di lingkungan kita harus selalu selalu up to date. Dilihat dari cara pengucapan kata atau bahasa yang digunakan, kemunculan "bahasa prokem" saat ini sangatlah menakjubkan, terutama di kalangan remaja.

3. Dampak Penggunaan Bahasa Prokem

Berdasarkan hasil penelitian penggunaan bahasa prokem pada remaja ini mempunyai dampak positif dan negatif. Semua hal mempunyai dampak positif dan negatif. Sama halnya dengan penggunaan bahasa prokem pastinya mempunyai dampak.

\section{1) Dampak Positif}

Dampak positif dari bahasa adalah anak-anak menjadi lebih kreatif. Terlepas dari apakah bahasa prokem ini mengganggu, tidak ada salahnya menikmati setiap perubahan atau inovasi dalam bahasa yang muncul setiap kurun waktu tertentu. Selama digunakan dalam kondisi yang tepat, media yang tepat dan komunikasi yang tepat juga baik-baik saja.

2) Dampak negatif

Pengaruh bahasa yang negatif dapat membuat pengguna sulit berbahasa Indonesia dengan benar. Bahkan di sekolah atau di tempat kerja, kita harus selalu menggunakan bahasa yang baik dan benar. Jika seseorang menggunakan bahasa Inggris untuk menyelesaikan pekerjaan rumah, tes atau tugas sekolah tidak memungkinkan. Oleh karena itu, ketika kita berada dalam situasi formal, mohon hentikan penggunaan kata-kata prokem untuk komunikasi.

\section{SIMPULAN DAN SARAN}

Pembahasan mengenai penggunaan bahasa prokem yang diteliti dapat ditarik kesimpulan. Penggunaan bahasa prokem yang digunakan oleh remaja Desa Kutanegara Kabupaten Karawang adalah ragam bahasa yang digunakan sehari-hari. Hasil analisis penggunaan bahasa yang digunakan oleh remaja di Desa Kutanegara Kabupaten Karawang terdapat 25 kata bahasa prokem yang digunakan pada sesama para remaja. Hasil tersebut didapatkan dengan cara obsevasi dan wawancara dengan para remaja di 
Desa Kutanegara Kabupaten Karawang. Semakin majunya peradaban zaman bahasa prokem tidak akan sampai di sini saja. Bahasa prokem akan semakin meluas dengan seiring berjalannya teknologi dan waktu. Teknologi sekarang ini, semakin canggih sehingga berita apa pun akan gampang tersebar. Bahasa prokem pun akan mudah menyebar ke berbagai daerah penjuru dan mudah diikuti. Banyaknya berita yang semakin up to date merupakan salah satu faktor penggunaan bahasa prokem pada remaja. Penggunaan bahasa prokem menimbulkan dampak positif dan negatif. Dampak positif penggunaan bahasa prokem salahsatunya adalah semakin banyak kosa kata baru. Dampak negatif dari penggunaan bahasa prokem adalah dikhawatirkan para remaja tidak paham bahasa Indonesia yang baik dan benar. Penelitian terhadap bahasa prokem tidak berhenti di sini saja. Seiring berjalannya zaman akan mengalami banyak perubahan. Banyak hal yang perlu dilakukan untuk memahami bahasa prokem secara mendalam.

\section{E. DAFTAR PUSTAKA}

Ismiyati. 2011. Bahasa Prokem di Kalangan Remaja Kotagede. Skripsi . Yogyakarta: Universitas Negeri Yogyakarta

Kridalaksana, Harimurti. 2009. Pembentukan Kata dalam Bahasa Indonesia. Jakarta : PT Gramedia Pustaka Utama.

Moleong. 2007. Metode Penelitian Kualitatif. Bandung : PT Remaja Rosdakarya

Sarwono, Sarlito W. 2016. Psikologis Remaja. Jakarta: Rajawali Pers.

Tarigan, Henry Guntur. 2008. Menulis sebagai Suatu Keterampilan Berbahasa. Bandung: Penerbit Angkasa. 